TRENDS IN DAILY PRECIPITATION ON THE NORTHEASTERN IBERIAN

PENINSULA, 1955-2006

López-Moreno, J.I ${ }^{1}$; Vicente-Serrano, S.M. ${ }^{1}$; Angulo, M. ${ }^{2}$; Beguería, S. ${ }^{2}$; Kenawy, A. ${ }^{1}$

(Short title: Trends in daily precipitation on the NE Iberian Peninsula)

Corresponding Author:

J. I. López-Moreno

Instituto Pirenaico de Ecología, CSIC (Spanish Research Council),

Campus de Aula Dei, P.O. Box 202,

Zaragoza 50080, Spain

Tlfn/Fax: +34 976716040/+34 976716039

E-mail: nlopez@ipe.csic.es 


\title{
TRENDS IN DAILY PRECIPITATION ON THE NORTHEASTERN IBERIAN PENINSULA, 1955-2006
}

\author{
López-Moreno, J.I ${ }^{1}$; Vicente-Serrano, S.M. ${ }^{1}$; Angulo, M. ${ }^{2}$; Beguería, S. ${ }^{2}$; Kenawy, A. ${ }^{1}$ \\ 1) Instituto Pirenaico de Ecología, CSIC (Spanish Research Council), Campus de Aula Dei, P.O. Box \\ 202, Zaragoza 50080, Spain \\ 2) Estación Experimental de Aula Dei CSIC (Spanish Research Council), Zaragoza, Spain.
}

\begin{abstract}
The temporal evolution of nine daily precipitation indices over the northeastern Iberian Peninsula was analyzed for the period 1955-2006, using data from 217 observatories. Cross-tabulation analysis enabled detection of statistically significant overlap among spatial distributions of trends in the study area. There was a general decrease in annual precipitation at most observatories, a decrease in the number of rainy days and precipitation intensity, and an increase in the duration of dry spells. The frequency and contribution to annual precipitation of moderate and heavy rainfall events did not change at most observatories, or showed a decreasing trend in these events. There was very large spatial and seasonal variability, with implications for water management and risk assessment in the region. The decrease in precipitation was very marked in headwaters during winter and spring, potentially affecting reservoir management in the region. Heavy rainfall events generally decreased in the west of the region in winter, and in the east of the region in autumn, when these areas are more exposed to hazards related to extreme rainfall. Large differences in the sign and magnitude of trends occurred over very short distances, suggesting the need for dense networks of observatories to ensure reliable and robust detection of regional trends.
\end{abstract}

Key words: Daily precipitation, temporal trends, spatial variability, cross-tabulation analysis, Iberian Peninsula.

\section{Introduction}

In recent decades, understanding and predicting climatic variability and change have become key issues for the research community. While it is now widely recognized that 
global temperature is increasing, changes in precipitation parameters are not well understood, although it is commonly accepted that they are complex and vary regionally. There is great interest in assessing changes in precipitation because of their importance to economic activities such as agriculture, energy production and drinking water supply, and due to their role in natural hazards such as droughts, floods, landslides and severe erosion. Two main directions in research into precipitation change are: i) simulation of precipitation under different future scenarios, in order to assess the magnitude and spatial distribution of expected changes; and ii) analysis of historical climate records to assess spatial patterns and the causes of temporal variability and change. Observational records are required to assess the quality of climate simulations during control periods. For these reasons the IPCC has recommended the development of dense and robust daily precipitation databases to enable analysis of trends in a number of indices (Jones et al., 1999; Karl et al., 1999; Nicholls and Murray, 1999; Moberg and Jones, 2005). However, there are problems with data availability and consistency that make it difficult to obtain a clear picture of worldwide extreme precipitation events (Karl et al., 1999).

A dense network of observatories worldwide, with long records of reliable quality, is not available. There are large areas for which appropriate records do not exist, or where data are not yet available from national archives. However, in recent decades an increasing number of researchers have been involved in gathering available meteorological records for specific regions (digitizing them when necessary and assessing their quality and homogeneity) in order to devise indices comparable to those recommended by the WMO CC1/COVER/JCOMM Expert Team on Climate Change Detection and Indices (http://cccma.seos.uvic.ca/etccdi).. As a result it has been possible to undertake trend analyses on daily precipitation indices in widely separated and contrasting geographical areas including the EEUU (Michaels et al., 2004), Central and South America (Aguilar et al., 2005), the UK (Osborn et al., 2000), Central and Western Europe (Moberg and Jones, 2005), Germany (Zolina et al., 2008), Switzerland (Schimidi and Frei, 2005), some parts of the Iberian Peninsula (Lana et al., 2004 and 2006; Martín-Vide, 2004; Casas et al., 2007; Martínez et al., 2007; Rodrigo and Trigo, 2007), Italy (Brunetti et al., 2000 and 2001), the Mediterranean region (Norrant and Douguédroit, 2006), India (Sen-Roi and Balling, 2004), Mongolia (Nandinsetseg, 2007), Australia (Suppiah and Hennessy, 1998; Haylock and Nichols, 2000), New 
Zealand (Salinger and Griffiths, 2001), South Africa (Kruger, 2006), and South East Asia and the South Pacific (Manton et al., 2001; Griffiths et al., 2003).

Here we present a trend analysis for a set of daily precipitation indices for the northeast area of the Iberian Peninsula over the period 1955-2006. The study was based on a recently created quality-controlled database comprised of 828 homogeneous series of daily precipitation records for the northeastern Iberian Peninsula (Vicente-Serrano et al.2008a). Among these are 217 continuous series covering the period 1955-2006. The research interest stems from a number of factors.

Firstly, the study area has an extraordinarily complex climate. Framed between the Atlantic Ocean to the northwest, and the Mediterranean Sea to the east, it encompasses an Atlantic-Mediterranean gradient in only a few hundred kilometers. In relief it is very heterogeneous, with flat areas such as the Ebro Valley, some coastal stretches, and mountainous areas including the Pyrenees, the Iberian Range, the Cantabrian Mountains and the Coastland Catalonian Range. This results in vertical gradients and barrier effects which modulate the regional or synoptic climatic conditions (Rodó et al., 1997; Rodríguez-Puebla et al., 1998; Martín-Vide and López-Bustins, 2006; Vicente-Serrano and López-Moreno, 2006; González-Hidalgo et al., 2008). Thus, contrasting spatial patterns of rainfall, and temporal variability and trends were expected. Such variability can be only analyzed using a dense network of observatories, such as the one used in the present study.

Secondly, water resource availability and water management is a major issue in the study area. Precipitation has large spatial variation, with several small humid zones (generally coinciding with mountainous headwaters) contributing most of the water required for agricultural and industrial activities, and for urban supply (López-Moreno et al., 2008). Consequently, spatial differences in the time evolution of precipitation across the area is not trivial, as the social impacts of changing precipitation will vary depending on which are the most severely affected areas.

Thirdly, natural hazards related to precipitation, particularly droughts and floods, are the most important in the region in terms of economic loss (Llasat and Rodríguez, 1992; White et al., 1997; Peñarrocha et al., 2002; Llasat et al., 2003, Vicente-Serrano, 2006). Precipitation in the Mediterranean region is one of the most variable in time and space worldwide, with water being relatively scarce throughout much of the year, but extreme precipitation events threaten lives and property on a small number of days per year 
(Lana and Burgueño, 1998; Beguería and Vicente-Serrano, 2006; Lana et al., 2006; Casas et al., 2007). In addition to natural variability, some studies have suggested trends in daily precipitation during the 20th century (Brunetti et al., 2000 and 2001; Gallego et al., 2006; Norrant and Douguedroit, 2006; Rodrigo and Trigo, 2007), and climate models predict marked changes in the frequency, intensity and duration of extreme events in the 21st century (Palutikof and Holt, 2004).

Although the main aim of the present study was to analyze the time evolution of daily precipitation indices on an annual basis, seasonal changes were also assessed. In addition, cross-tabulation analysis was used to explore pairwise relationships between indices, which enabled detection of spatial associations among trends for the analyzed parameters.

\section{Study area}

The study area comprises about $160,000 \mathrm{~km}^{2}$ in the northeast of Spain (Fig. 1), with boundaries corresponding to administrative areas including 18 provinces. The study area has strongly contrasting relief. The main unit is the Ebro Valley, an interior depression surrounded by high mountain ranges. It is bounded to the north by the Cantabrian Range and the Pyrenees, with maximum elevations above $3000 \mathrm{~m}$ a.s.1. The Iberian Range encloses the Ebro Valley to the south, with maximum elevations in the range of 2000-2300 m. To the west of the study area the main unit is the Meseta, a plain with elevations ranging between 700 and $900 \mathrm{~m}$ a.s.l. To the east, parallel to the Mediterranean coast, the Catalan Coastal Range sharply closes the Ebro Valley, with maximum elevations between 1000 and $1200 \mathrm{~m}$ a.s.1.

The heterogeneous topography, contrasting influences of Atlantic (westward) and Mediterranean (eastward) conditions, and the influence of various winds (VicenteSerrano and López-Moreno, 2006) generates a complex spatial distribution of climate parameters, and variations in precipitation and temperature throughout the region (Ninyerola et al., 2005). Thus, annual precipitation varies from 307 to $2451 \mathrm{~mm} \mathrm{yr}^{-1}$. 
Most of the precipitation falls in autumn and spring (García-Ruiz et al., 2001). The summer is relatively dry (with occasional rainstorms), as is the winter, when extended anticyclonic periods occur. However, in the westernmost part of the study area the winters are more humid because of continuous exposure to the passage of oceanic fronts. Average annual temperature varies from 0.8 to $16.2^{\circ} \mathrm{C}$.

\section{Methods}

\subsection{Database}

A database comprising 217 complete daily precipitation series with continuous data between January 1955 and December 2006 was used. The series were obtained through a process that included reconstruction, gap filling, quality control and homogenization testing (see details in Vicente-Serrano et al., 2008a). Although the original database contained 828 data series, some more than 80 years in length, we selected the period from 1955 to 2006 to achieve an appropriate balance between the spatial density of observatories and length of the series. The series have a rather homogeneous distribution across the study area, with a slightly higher concentration in the coastal Mediterranean (Fig. 1).

We selected nine indices describing different aspects of the precipitation regime, many of which have been used in previous studies (e.g. Moberg and Jones, 2005; Nicholls and Murray, 1999). Values of each index were calculated on an annual basis and for the different seasons: December to February (DJF), March to May (MAM), June to August (JJA) and September to November (SON).

Table 1 provides the acronyms and a short definition of the selected indices. $\mathrm{P}$ is the cumulative precipitation during the analysis period; WD is the number of days with precipitation higher than $1 \mathrm{~mm}$; PI is the average precipitation per wet day; C90, R90N 
and R90T are, respectively, the intensity, frequency and contribution of heavy rainfall events to total precipitation, i.e. those days exceeding the 90th percentile of the series; R5GD is the cumulative precipitation of the five most intense events; WS is the length of the longest wet spell, i.e. a series of consecutive rainy days; and DS is the length of the longest dry spell, i.e. a series of consecutive days with no rain.

\subsection{Statistical analysis}

A trend analysis was performed on the time series of the nine indices, using the Spearman's rank correlation test, which is less affected by the presence of outliers and non-normality in the series (Lanzante, 1996). Both sets of data $X_{i}$ (year i) and $Y_{i}$ (value of the precipitation index for $\mathrm{Xi}$ ) were converted to ranks $x_{i}$ and $y_{i}$ before calculating the coefficient, $\rho$, which is given by:

$$
\rho=\frac{6 \sum d_{i}^{2}}{n\left(n^{2}-1\right)},
$$

where $d_{i}=x_{i}-y_{i}$ (the difference between the ranks of corresponding values of $\mathrm{X}_{\mathrm{i}}$ and $\mathrm{Y}_{\mathrm{i}}$ ), and $n$ is the number of values in the data set. Statistically significant trends where defined as those below the threshold $p<0.05$.

To distinguish more persistent trends, year to year variation in the series was smoothed using a nine year Gaussian filter. This is an established procedure in climate studies (e.g. Sneyers, 1992; Wheeler and Martín-Vide, 1992; Hulme, 1995; Salinger et al., 1995; De Luis et al., 2000; Domonikos, 2003). The filter smoothes the signal and removes excessive detail and noise by convolution with a Gaussian function. It is similar to a running average filter, but uses a kernel that represents the shape of a Gaussian hump ("bell-shaped") instead of regular weighting. This transformation is 
designed to prevent overshoot in a step function input while minimizing the rise and fall time. To map the percentage change of each index per decade, the magnitude of change was also calculated using a least square regression applied to the unfiltered data.

To test the association between pairs of indices with respect to their temporal trends, a cross-tabulation analysis was conducted. This method is commonly used to explore pairwise relationships among two or more categorical variables. It was used in this study to assess the coherence in spatial distributions of trend signs (positive, stationary and negative trends) among pairs of indices. This allowed detection of statistical similarities among the spatial distributions of the trends in precipitation indices. Statistical assessment of the overlaps used chi-squared $\left(\chi^{2}\right)$ test. Pivot tables were constructed to represent the cross-categorized frequency data in a matrix format, from the results of the trend analysis. The meteorological observatories $(n=217)$ were included as the random variable, and the "characteristics" of the random variable were the signs of the trend analysis (i.e. negative, stationary and positive). The trend categories were converted to scores (negative $=-1$, non-significant $=0$ and positive $=$ 1). The default structure of the consistency tables was $3 \times 3$. Table 2 shows two of the cross-tables used in this study. Of particular interest was whether any precipitation indices had a spatial distribution similar to a given index. The $\chi^{2}$ test is commonly used to test the significance of the association between categorical variables, and it has been applied to trend analysis of climate variables (a full description of the method and the computation of Chi-squared statistic may be found in Gonzalez Hidalgo et al., 2003). The null hypothesis $\left(\mathrm{H}_{0}\right)$ is that the spatial distribution of two categorical variables is independent and randomly distributed. The alternative hypothesis $\left(\mathrm{H}_{1}\right)$ is that the spatial association between two categorical variables is significant. When the null hypothesis is rejected, the degree to which the categorical variables are associated can be calculated 
by the coefficient of contingency (CC; Clark and Hosking, 1986), which ranges from 0 to 1 and is calculated as follows:

$$
C C=\sqrt{\frac{\chi^{2}}{n+\chi^{2}}} .
$$

\section{Results}

\subsection{Spatial distribution of average daily precipitation indices}

Figure 2 shows the mean annual values of eight of the precipitation indices over the study period. The spatial distribution of R90N is not shown because it had the same value at all observatories.

The mean magnitude of the precipitation indices varied markedly throughout the study area, as a consequence of the climatic heterogeneity of the region. There was a marked gradient in $\mathrm{P}$, from less than $400 \mathrm{~mm}$ in the centre of the Ebro Depression to more than $1500 \mathrm{~mm}$ in the Pyrenees, at the north of the study area. WD ranged from less than 50 to more than 110 rainy days per year, and a clear negative trend in this index was apparent along a northwest-southeast gradient. The spatial distribution of PI showed the highest intensities (PI $>10 \mathrm{~mm}$ ) occurred along the Mediterranean coast and in the central Pyrenees, whereas the lowest intensities (PI $<7 \mathrm{~mm}$ ) were found in the southwest of the study area.

The spatial distribution of the 90th percentile (C90) and the percentage contributing to total precipitation (R90T) were similar to those observed for PI, with the greatest frequency and contribution of heavy rainfall events $(>90 \mathrm{C})$ to total precipitation occurring along the Mediterranean coast and in some sectors of the north, and the lowest contribution occurring towards the southwest of the study area. The highest R5GD (cumulative precipitation of the 5 heaviest rainfall events in the year) values, 
exceeding $200 \mathrm{~mm}$ per year, occurred in the north of the study area. The Mediterranean coast had values close to these, whereas in the southwest of the study area the value did not exceed $150 \mathrm{~mm}$. WS and DS had opposite spatial distributions. Thus, the longest wet spells (more than 9 consecutive rainy days) as well as the shortest dry spells (less than 30 consecutive dry days) occurred in the northwest of the study area. There was a rapid change in these values along a southeast gradient. Thus, wet spells in the southernmost part (Mediterranean coast) and in the eastern part of the Ebro Valley did not exceed 5 days, whereas the average daily dry spell was greater than 45 days.

\subsection{Trends in daily precipitation indices}

Figure 3 shows the annual evolution of $\mathrm{P}$ and temporal trends for the period 19552006 at three selected observatories. The evolution of P exhibited large inter-annual variability at all three observatories, and also marked inter-decadal cycles that did not always coincide among the series. Moreover, the opposing sign of the trends confirms the existence of contrasted patterns in temporal evolution of precipitation over relatively short distances in the study area.

Figure 4 shows the trend sign and percentage change per decade for the nine precipitation indices. Appendices I, II, III and IV present the same data as Figure 4, but for winter, spring, summer and autumn, respectively. Table 3 shows the percentage of observatories with positive, stationary and negative trends.

These was a negative trend in $\mathrm{P}$ across the whole region. The trend was statistically significant at 149 observatories (67\% of total), there was no significant trend at 69 observatories (32\%), and only 2 observatories (less than 1\%) exhibited a significant upward trend in precipitation. Results of the seasonal analysis (see appendices I to IV) showed that the negative trend was consistent throughout the year at most observatories, although several seasonal and spatial differences where found. Thus, winter had the greatest number of observatories (59\%) showing a significant decrease in precipitation, while the remaining $41 \%$, mostly clustered along the Mediterranean coastline, showed no significant change. Negative trends also dominated in spring and summer, but most observatories (57\% and 54\%, respectively) showed no significant changes. The decrease in precipitation occurred mainly in the north of the study area during spring, and in the 
northeast and southernmost parts in summer. Almost no positive trends in precipitation were observed from winter to the end of summer. In autumn, significant decreases in precipitation (20\% of the observatories) were mainly centered in the Mediterranean area, although most did not exhibit significant trends, and significant increases (16 observatories, $7 \%$ of total) were found in the north and westernmost parts of the area.

The number of wet days generally decreased at the observatories, with significant declines at 54\%, positive trends at 7\% (apparently randomly distributed across the study area), and 39\% did not change significantly. As with total precipitation, the greatest number of observatories (59\%) exhibited a significant decrease in wet days in winter, and only 3\% showed a significant increase. During autumn the majority of observatories showed no significant trend (72\%), whereas $26 \%$ showed a positive trend. Only four observatories had a negative trend.

The mean daily precipitation intensity (PI) was also characterized on an annual basis by a dominance of observatories with negative trends, with $44 \%$ being statistically significant. However a significant increase in PI was also detected at $14 \%$ of observatories. Seasonal maps (see appendices) showed that there were similar proportions of observatories with trends of each sign in winter, spring and summer than proportions shown at the annual basis; in autumn a tendency towards less precipitation per rainy day was detected.

At the majority of observatories (48\%) the amount of rainfall corresponding to the annual 90th percentile (C90) tended to remain stationary. However, a negative trend was observed at $41 \%$ of observatories (mostly located in the central part of the study area), whilst at $11 \%$ the annual 90th percentile tended to increase. Similar observations were made in relation to season: in autumn the number of observatories with positive trends fell to $3.5 \%$, and in the eastern part of the study area no observatory showed a positive trend.

A generalized decrease ( $49 \%$ of observatories) or no change ( $46 \%$ of observatories) was found for the long-term 90th percentile (R90N). The central Ebro Valley had the greatest concentration of observatories with a significant R90N decrease, as occurred with C90. On a seasonal basis, the percentage of observatories with an upward trend in R90N never exceeded 7\%, and observatories with no change dominated. In winter and spring the downward trend in R90N tended to be concentrated in observatories in the western part of the study area, whereas an opposite spatial behavior occurred in summer and autumn. The contribution of C90 events to annual precipitation (R90T) did not 
change over most of the study area (62\% of observatories), but $29 \%$ of observatories (most located in central and western parts) showed a significant decrease in the contribution of moderately extreme events, and 9\% (mainly in the north) showed an increase. The percentage of observatories with trends of each sign was maintained throughout the different seasons, with few differences in their spatial distribution.

The index of accumulated rainfall during the five days with heaviest rainfall (R5GD) is related to the most intense rainfall events. It remained unchanged at the majority of observatories $(50 \%)$, particularly in the east of the study area. A large number of observatories (44\%), mainly in central parts, showed a decrease for this index, and only $6 \%$ of observatories showed an upward trend. On a seasonal basis, percentages of observatories with different trends did not show noticeable changes relative to the annual results. In winter and spring most of the observatories with stationary or upward trends were located in the Mediterranean coastal areas, and the contrary occurred in summer and autumn. The length of both wet and dry periods (WS, DS) did not change at most $(60 \%)$ observatories. Negative trends in WS occurred at $30 \%$ of the observatories, and 10\% had positive trends. Positive trends in DS occurred at $38 \%$ of the observatories, and only $5 \%$ had negative trends. Some notable differences were found in the seasonal analysis. Thus, the annual pattern of WS was very similar in winter and spring, but in summer the number of observatories with significant negative trends $(50 \%)$ slightly exceeded the number of observatories that remained unchanged; in autumn, $8 \%$ of observatories showed negative trends and $19 \%$ had positive trends. The greatest number of observatories with significant positive trends in DS occurred in winter and summer (23 and 31\% respectively), and these were located primarily on the Mediterranean coast and some parts of the inner Ebro Depression. In autumn, DS did not change at $71 \%$ of the observatories, decreased at $20 \%$, and increased at $9 \%$.

\subsection{Spatial association of trends in daily precipitation indices}

Table 4 shows the results of the cross-tabulation analysis conducted amongst the nine daily precipitation indices. The occurrence of significant associations and high coefficients of contingency suggests that the trends were closely related. Thus, the general decrease in precipitation in the study area appeared to be related to the decrease in the average intensity of precipitation (PI) and the general decrease in the frequency and magnitude of heavy rainfall events (C90, R90N, R90T and R5GD), and also with the increase in the length of dry spells. Despite the general negative trend for the 
number of wet days (WD) and the duration of wet spells (WS), the spatial distribution of trend signs exhibited significant variation, suggesting that trends in precipitation amount (P) were unrelated to WD and WS. Thus, coefficients of contingency were quite low, and the chi-squared test did not show any statistical significance. Figure 5 reinforces the results of the cross-tabulation analysis, as it shows a significant linear correlation between the spatial pattern of trends (Spearman's rho coefficients) in P and two highly spatially-associated variables (PI and R5GD; Figs 5a and 5b, respectively). In addition, there was no evidence of a statistical relationship between P and WD (Fig. $5 \mathrm{c})$, despite a dominance of negative trends for both indices.

The spatial patterns of indices reflecting heavy rainfall events (C90, R90, R90T and R5GD) were significantly related to PI with high coefficients of contingency. For example, there was a very high correlation $(\mathrm{r}=0.88)$ between the spatial patterns of $\mathrm{C} 90$ and PI, and also between C90 and R5GD (Fig. 6). The positive trend in DS appeared to be statistically related to a decrease in P and WD.

Appendix 5 shows the coefficients of contingency from the cross-tabulation analysis, calculated on a seasonal basis. The results show that, with minor differences, the spatial associations for the annual indices also occurred for the seasonal analysis.

\section{Discussion and conclussions}

In this study we analyzed trends in a set of daily precipitation indices for the northeastern Iberian Peninsula for the period 1955-2006. The study was based on a quality-controlled and homogenized database consisting of 217 observatories. Changes in the daily amount and distribution of precipitation have important implications because agriculture and water supply are often limited by water availability in the study area, and because heavy rainfall events constitute a major natural hazard in the region. The main findings were: (i) annual precipitation $(\mathrm{P})$ decreased at the majority $(67 \%)$ of observatories, did not change at $32 \%$, and showed a positive trend at only $1 \%$. The decrease in $\mathrm{P}$ was particularly marked in winter and spring, whilst in summer and autumn stationary trends dominated; (ii) the number of rainy days (WD) and the average precipitation intensity (PI) generally decreased. Most of the negative trends in WD occurred in winter and summer, whereas the decrease in PI was particularly intense in autumn; (iii) indices related to the frequency, magnitude and contribution of moderately heavy precipitation events to total P (C90, R90N, R90T) had negative trends 
at many observatories, although the majority remained unchanged. Only at a small number of observatories did the importance of heavy rainfall events increase with the time; (iv) the duration of wet and dry spells remained unchanged at most observatories (61\% and 57\%, respectively), but $30 \%$ had negative trends in WS, and $38 \%$ had positive trends in DS; (v) the spatial and seasonal distribution of trends in the indices varied considerably; (vi) statistically significant spatial associations were found between the trends for annual precipitation (P) and average daily precipitation intensity (PI). However, while many observatories had negative trends in the number of rainy days (WD), there was no spatial or significant relationship with trends in P. The crosstabulation analysis suggested a strong relationship between the spatial patterns of the trends in P and those of C90, R90N and R90T.

The availability of a dense network of observatories in the region enabled robust signals related to the temporal evolution of precipitation indices across the study area to be distinguished. Identified patterns were based on locations sharing a common trend sign. However, for the majority of indices there were observatories that differed from the general trend, and even exhibited an opposite evolution. This may explain why studies of the evolution of daily precipitation do not always coincide for southern Europe, and even within the study area. A common finding in previous research has been a marked decrease in total precipitation in the region. A negative trend in $\mathrm{P}$ has previously been found for several areas of southern Europe and the Mediterranean basin including the maritime Alps (Auer et al., 2007), Italy (Piccareta et al., 2004; Brunetti et al., 2006) and Greece (Norrant and Douguedroit, 2006). In the Iberian Peninsula, most previous research has pointed to a decrease in precipitation (e.g. Goodess and Jones, 2002; Rodrigo and Trigo, 2007; González-Hidalgo et al., 2008), and most studies have also reported that the largest decreases occur in winter as a consequence of regional circulation patterns, particularly in relation to the recent evolution of the NAO, AO and WEMO indices (Vicente-Serrano and López-Moreno, 2006; Rodrigo and Trigo, 2007; López-Bustins et al., 2008). The strength of the negative trend of winter precipitation in the Iberian Peninsula, has been often associated to a marked drying of March (González-Hidalgo et al., 2008, Sánchez-Lorenzo et al. 2007). A similar finding was obtained for the study area from the analysis of monthly regional series (López-Moreno et al., 2008).

In contrast to the consistency of our findings with those of previous studies with respect to the evolution of $\mathrm{P}$, we found different trends in PI and in the magnitude and 
contribution of heavy precipitation events to total P. Several studies conducted for a similar period than our study in the Mediterranean basin reported an increase of PI and extreme events (Brunetti et al., 2001; Norrant and Douguedroit, 2006). Goodess and Jones (2002) reported that areas of the Iberian Peninsula exposed to Mediterranean influences had a tendency towards a lower number of rainy days with higher precipitation amounts, in line with the findings of Ramos and Martinez-Casanovas (2006), who detected an increase in precipitation intensity at several observatories in Catalonia (northeast Spain). In contrast, Rodrigo and Trigo (2007) found that in general there was a greater decrease in precipitation intensity than in the number of rainy days. Martinez et al. (2007) reported an increase in the contribution of light and moderate events to total precipitation, and De Luis et al. (2000) and González-Hidalgo et al. (2003) suggested that torrential precipitation events may have diminished in magnitude on the Mediterranean coast south of the present study area. Our study showed that precipitation intensity at most of the observatories has remained unchanged or has decreased with time, and only at a very small percentage of observatories was there a significant increase. Similar results were found for C90, R90N, R90T and R5GD, indicating a negative trend in the heaviest precipitation events. It is known that parameters relating to intense rainfall usually have high spatial and temporal variability, especially in the Mediterranean region (García-Ruiz et al., 2000). Thus different and even opposing trends were found at adjacent observatories. Reliable results for the region can only be obtained with a spatially dense observatory network, as in our study.

The spatial and seasonal differences found in the evolution of precipitation indices have important implications for water management and risk assessment in the region. Thus, decreased precipitation was general in the region, but particularly affected the Pyrenean headwaters, the main area for generation of runoff in the Ebro Valley in winter and spring. These periods are the most humid in that region, and determine the water supply for many reservoirs during the dry months (López-Moreno et al., 2004 and 2008).

Heavy rainfall events and their contribution to $\mathrm{P}$ exhibited a stationary or decreasing evolution in the Atlantic areas in winter, and across the Mediterranean coastal area in autumn. This indicates that major risks associated with heavy rainfall should not have increased during recent decades, as most damaging events occur in winter and autumn in the Atlantic and Mediterranean regions, respectively (García-Ruiz et al., 2001). The stationary or decreasing trends in the evolution of indices related to heavy rainfall in 
autumn for the Mediterranean coast contrasts with the evolution of extreme precipitation events projected by climate models for the Mediterranean basin (Gao et al., 2006), including the study area (López-Moreno and Beniston, 2008). Another contrast between model projections and the trends observed in this study was in the mean dry spell length, which is predicted to increase in coming decades (Rowell and Jones, 2006; López-Moreno et al., 2008). Analysis of the instrumental series did not provide any indication that changes in this direction have begun. Such contradictions do not place in question the overall validity of climate change projections, since the response of precipitation to increasing greenhouse gas emissions is highly non-linear, and is also linked to derived shifts in atmospheric circulation patterns (Vicente-Serrano and López-Moreno, 2008b). However, further research into the coherences and divergences between recent climate trends and model projections may improve the assessment of uncertainty associated with future climate conditions and their impact.

\section{Acknowledgments}

This study was supported by the PROBASE projects CGL2006-11619 and CGL2008-01189/BTE, both financed by the Spanish Commission of Science and Technology (Ministry of Education and Science)and FEDER, and the FP7 EU project ACQWA (Assessing Climatic Change and Impact on the Quantity and Quality of Water). 


\section{References}

Aguilar E., Peterson TC, Obando P, Ramírez J, Frutos R, Retana JA, Solera M, Soley J, García I, González L., Araujo RM, Santos A, Rosa M, Valle V, Brunet M, Aguilar L, Álvarez L, Bautista M, Castañón C, Herrera L, Ruano E, Sinay J J, Sánchez E, Oviedo G, Hernández I, Obed F, Salgado J E, Vázquez JL, Baca M, Gutiérrez M, Centella C, Espinosa J, Martínez D, Olmedo B, Espinoza C, Ojeda E, Núñez R, Haylock M, Benavides H, Mayorga R. 2005. Changes in precipitation and temperature extremes in Central America and northern South America, 1961-2003. J. Geophys. Res. 110: D23107

Alexandersson H. 1986. A homogeneity test applied to precipitation data. Journal of Climatology 6: 661-675.

Alexandersson H, Moberg A. 1997. Homogenization of Swedish temeperature data. Part I: Homogeneity test for lineal trends. International Journal of Climatology 17: 25-34.

Auer I, Böhm R, Jurkovic A, Lipa W, Orlik A, Potzmann R, Schöner W, Ungersböck M, Matulla C, Briffa K, Jones P, Efthymiadis D, Brunetti M, Nanni T, Maugeri M, Mercalli L, Mestre O, Moisselin J-M, Begert M, Müller-Westermeier G, Kveton V, Bochnicek O, Stastny P, Lapin M, Szalai S, Szentimrey T, Cegnar T, Dolinar M, Gajic-Capka M, Zaninovic K, Majstorovic Z, Nieplova E. 2007. HISTALP historical instrumental climatological surface time series of the Greater Alpine Region. International Journal of Climatology 27 (1): 17-46.

Begueria S, Vicente Serrano SM. 2006. Mapping the hazard of extreme rainfall by peaks-over-threshold extreme value analysis and spatial regression techniques. Journal of Applied Meteorology and Climatology 45: 108-124.

Beguería S, Vicente-Serrano SM, López-Moreno JI, García-Ruiz JM. 2008. Annual and seasonal mapping of peak intensity, magnitude and duration of extreme precipitation events across a climatic gradient, North-east Iberian Peninsula. International Journal of Climatology, on-line first.

Brunetti M, Buffoni L, Maugeri M, Nanni T. 2000. Precipitation intensity trends in northern Italy. International Journal of Climatolology 20: 1017-1031.

Brunetti M, Maugeri M, Nanni T. 2001. Changes in total precipitation, rainy days and extreme events in northeastern Italy. Int. J. Climatol. 21: 861-871.

Brunetti M, Maugueri M, Monti F. Tatti T. 2006. Temperature and precipitation variability in Italy in the last two centuries from homogenized instrumental time series. International Journal of Climatology 26: 345-381.

Casas MC, Herrero M, Ninyerola M, Pons X, Rodríguez R, Rius A, Redaño A. 2007. Analysis and objective mapping of extreme daily rainfall in Catalonia. International Journal of Climatology 27: 399-409.

Clark W.A.V, Hosking P.L. 1986. Statistical Methods for Geographers. Ed. Jhon Willey \& Sons. New York 528p.

De Luís M, Raventós J, González-Hidalgo JC, Sánchez JR, Cortina J. 2000. Spatial analysis of rainfall trends in the region of Valencia (East Spain), International Journal of Climatology 20: 1451-1469.

Domonikos P 2003. Recent precipitation trends in Hungary in the context of larger scales climatic changes. Natural Hazards 29 (2): 255-271. 
Gallego MC, García JA, Vaquero JM. 2006. The NAO signal in daily rainfall series over the Iberian Peninsula. Climate Research 29: 103-109.

Gao X, Pal JS, Giorgi F.2006. Projected changes in mean and extreme precipitation over the Mediterranean region from a high resolution double nested RCM simulation, Geophys. Res. Lett. 33: L03706

García-Ruiz JM, Arnáez JM, White S, Lorente A, Beguería S. 2000. Uncertainty assessment in the prediction of extreme rainfall events: an example from the Central Spanish Pyrenees. Hydrological Processes 14: 887-898.

García-Ruiz JM, Beguería S, López-Moreno JI, Lorente-Grima A, Seeger M. 2001. "Los recursos hídricos superficiales del Pirineo aragonés y su evolución reciente". Geoforma Ediciones, Logroño, 191 pp.

López-Moreno, J.I. and García-Ruiz, J.M. (2007). Hydrological effects of reservoirs in the Central Spanish Pyrenees. En: Robinson, P.J., J.A.A. Jones and M-K Woo (eds) 2007: Managing water resources in a changing physical and social environment. IGU Home of Geography Publication Series, Società Geografica Italiana, Rome, 177pp, p. 103-114.

González-Hidalgo JC, De Luis M, Raventós J, Sánchez JR. 2003. Daily rainfall trend in the Valencia Region of Spain. Theoretical and Applied Climatology 75: 117-130.

González-Hidalgo JC, López-Bustins JA, Štepánek P, Martín-Vide J, de Luis M. 2008. Monthly precipitation trends on the Mediterranean fringe of the Iberian Peninsula during the second half of the 20th century (1951-2000). International Journal of Climatology, on line first.

Griffiths GM, Salinger MJ, Leleu I. 2003. Trends in extreme daily rainfall across the South Pacific and relationship to the South Pacific convergence zone. International Journal of Climatology 23: 847-869.

Goodess CM, Jones PD. 2002. Links between circulation and changes in the characteristics of Iberian rainfall. International Journal of Climatology 22: 15931615.

Haylock M, Nicholls N. 2000. Trends in extreme rainfall indices for an updated high quality data set for Australia, 1910-1998. International Journal of Climatology 20: 1533-1541.

Hulme M. 1995. Estimating global changes in precipitation. Weather 50 (2): 34-42.

Hulme M, Conway D, Jones PD, Jiang T, Barrow EM, Turney C, (1995). Construction of a 1961-1990 European climatology for climate change modelling and impact applications. International Journal of Climatology 15: 1333-1363.

Jones P.D., Horton E.B., Folland C.K., Hulme, M., Parker D.E. and Bassnett T.A. 1999. The use of indices to identify changes in climatic extremes. Climatic Change 42 (1): 131-149.

Karl TR, Nicholls N, Ghazi A. 1999. Clivar/GCOS/WMO Workshop on Indices and Indicators for Climate Extreme Workshop Summary. Climatic Change 42 (1): 3-7.

Keiser DT, Griffiths JF. 1997. Problems Associated with Homogeneity Testing in Climate Variations Studies: A Case Study of Temperature in the Northern Great Plains, USA. International Journal of Climatology 17: 497-510

Kruger A.C. 2006. Observed trends in daily precipitation indices in south Africa: 19102004. International Journal of Climatology, 26: 2275-2285. 
Lana X, Burgueño A. 1998. Probabilities of repeated long dry episodies based on the poisson distribution. Theoretical and Applied Climatology 60 : 111-120.

Lana X, Martínez MD, Serra C, Burgueño A. 2004. Spatial and temporal variability of the daily rainfall regime in Catalonia (NE Spain), 1950-2000" International Journal of Climatology 24: 613-641.

Lana X, Martinez MD, Burgueño A., Serra C, Martin-Vide J, Gomez L. 2006. Distributions of long dry spells in the Iberian Peninsula, years 1951-1990. Internacional Journal of Climatology 26: 1999-2021.

Lanzante JR. 1996. Resistant, robust and non-parametric techniques for the analysis of climate data: theory and examples, including applications to historical radiosonde observatorie data. International Journal of Climatology 16: 1197-1226.

Llasat MC, Rodríguez R. 1992. Extreme rainfall events in Catalonia. The case of 12 November 1988. Natural Hazards 5: 133-151.

Llasat MD, Rigo T, Barriendos M 2003. The 'Montserrat-2000' flash-flood event: A comparison with the floods that have occurred in the northeastern Iberian Peninsula since the 14th century. International Journal of Climatology 23: 453-469.

López-Bustins JA, Martín-Vide J, Sanchez-Lorenzo A. 2008. Iberia winter rainfall trends based upon changes in teleconnection and circulation patterns. Global and Planetary Change 63: 171-176.

López-Moreno JI, Beguería S, García-Ruiz JM. 2004 The management of a large mediterranean reservoir: storage regimes of the Yesa reservoir, Upper Aragón River basin, Central Spanish Pyrenees. Environmental Management 34 (4): 508-515.

López-Moreno, J.I., García-Ruiz, J.M. and Beniston, M. 2008. Environmental Change and water management in the Pyrenees. Facts and future perspectives for Mediterranean mountains. Global and Planetary Change 66 (3-4): 300-312.

López-Moreno, J.I. and Beniston, M. 2009. Daily intensity precipitation for the 21st century: seasonal changes over an Atlantic-Mediterranean gradient in the Pyrenean mountains. Theoretical and Applied Climatology 95: 375-384

Manton MJ, Della-Marta PM, Haylock MR, Hennessy KJ, Nicholls N, Chambers LE, Collins DA, Daw G, Finet A, Gunawan D, Inape K, Isobe H, Kestin TS, Lefale P, Leyu CH, Lwin T, Maitrepierre L, Ouprasitwong N, Page CM, Pahalad J, Plummer N, Salinger MJ, Suppiah R, Tran VL, Trewin B, Tibig I, Yee D. 2001. Trends in extreme daily rainfall and temperature in Southeast Asia and the South Pacific: 1961-1998. International Journal of Climatology 21: 269-284.

Martin-Vide J. 2004. Spatial distribution of a daily precipitation concentration index in peninsular Spain. International Journal of Climatology 24: 959-971.

Martin-Vide J, López-Bustins JA. 2006. The Western Mediterranean Oscillation and rainfall in the Iberian Peninsula. International Journal of Climatology 26 (11): 1455-1475.

Martínez MD, X Lana, A Burgueño, C Serra. 2007. Spatial and temporal daily rainfall regime in Catalonia (NE Spain) derived from four precipitation indices, years 19502000, International Journal of Climatology 27 (1):1527-1632.

Michaels PJ, Knappenberg PC, Fraunfeld OW, Davis RE 2004. Trends in precipitation on the wettest days of the year across contiguous USA. International Journal of Climatology 24 (15): 1873-1882. 
Moberg A, Jones P. 2005. Trends in indices for extremes in daily temperature and precipitation in central and western Europe. International Journal of Climatology 25: $1149-1171$.

Nandintsetseg B, Greene S, Goulden CE. 2007. Trends in extreme daily precipitation and temperature near Lake Hövsgöl. International Journal of Climatology 27:341347.

Ninyerola M, Pons X, Roure JM. 2005. Atlas Climático Digital de la Península Ibérica. Ed. Universitat Autonoma de Barcelona. Barcelona, 45pp.

Norrant C., Douguédroit A. (2006). Monthly and daily precipitation trends in the Mediterranean (1950-2000). Theoretical and Applied Climatology 83: 89-106.

Osborn T, Hulme M, Jones PD, Basnett TA. 2000. Observed trends in the daily intensity of United Kingdom precipitation. International Journal of Climatology 20: 347-364.

Palutikof JP, Holt T. 2004. Climate change and the occurrence of extremes: some implications for the Mediterranean Basin. Chapter 4 in: Environmental Challenges in the Mediterranean 2000-2050 (Ed. A. Marquina), pp.61-73 Kluwer Academic Publishers.

Peñarrocha D, Estrela MJ, Millán M. 2002. Classification of daily rainfall patterns in a Mediterranean area with extreme intensity levels: the Valencia region. International Journal of Climatology 22: 677-695.

Piccareta M, Capolongo D, Boenzi F. 2004. Trend analysis of precipitation and drought in Basilicata from 1923 to 2000 within a southern Italy context. International Journal of Climatology 24:907-922.

Ramos MC, Martinez-Cassanovas JA 2006. Trends in precipitation concentration and extremes in the Mediterranean Penédes-Anoia Region, NE Spain. Climatic Change 74: 457-474.

Rodó X, Baert E, Comín FA. 1997. Variations in seasonal rainfall in southern Europe during the present century: relationships with the North Atlantic Oscillation and the El Niño-Southern oscillation. Climate Dynamics 13: 275-284.

Rodríguez-Puebla C, Encinas AH, Nieto S, Garmendia J. 1998. Spatial and temporal patterns of annual precipitation variability over the Iberian Peninsula. International Journal of Climatology 18: 299-316.

Rodrigo FS, Trigo RM. 2007. Trends in daily rainfall in the Iberian Peninsula from 1951 to 2002. International Journal of Climatology 27: 513-529

Rowell DP, Jones RG. 2006. Causes and uncertainty of future summer drying over Europe. Climate Dynamics 27 (2-3): 281-299.

Salinger MJ, Basher RE, Fitzharris BB, Hay JE, Jones PD, Macveigh JP, SchmidelyLeleu I. 1995. Climate trends in the south-west Pacific. International Journal of Climatology 15: 285-302.

Salinger MJ, Griffiths G.M. 2001. Trends in New Zealand daily temperature and rainfall extremes. International Journal of Climatology 21: 1437-1452.

Sanchez-Lorenzo A, Brunetti M, Calbó J, Martin-Vide J. 2007. Recent spatial and temporal variability and trends of sunshine duration over the Iberian Peninsula from homogenized dataset. Journal of Geophysical Research - Atmosphere 112: D20115, 
Schimidi J, Frei C. 2005. Trends of heavy precipitation and wet and dry spells in Switzerland during the $20^{\text {th }}$ century. International Journal of Climatology 25: 753771.

Sen-Roy S. and Balling R.C. 2004. Trends in extreme daily precipitation indices in India. International Journal of Climatology 24: 457-466.

Sneyers R 1992. Use and misuse of statistical methods for detection of climatic change. In: Climate Change Detection Project. Report on the Informal Planning Meeting on Statistical Procedures for Climate Change Detection. WCDMP 20. WMO.

Suppiah R, Hennessy KJ. 1998. Trends in total rainfall, heavy rain events and number of dry days in Australia, 1910-1990. International Journal of Climatology 10: 11411164.

Vicente-Serrano S, López-Moreno JI. 2006. Influence of atmospheric circulation at different spatial scales on winter drought variability through a semiarid climatic gradient in Nort-east Spain. International Journal of Climatology 26 (11): 14271453.

Vicente-Serrano SM, Beguería S, López-Moreno JI, García-Vera MA, Stepanek P. 2008a. A complete daily precipitation database for North-East Spain: reconstruction, quality control and homogeneity. International Journal of Climatology, on-line first.

Vicente-Serrano SM, López-Moreno JI. 2008b. Differences in the nonstationary influence of the North Atlantic Oscillation on European precipitation under different scenarios of greenhouse gases concentrations. Geophysical Research Letters 35, GL034832.

Wheeler D, Martín-Vide J. 1992. Rainfall characteristics of mainland Europe's most southerly observatories. International Journal of Climatology 12: 69-76.

White S, García-Ruiz JM, Martí C, Valero B, Errea MP, Gómez-Villar A. 1997. The 1996 Biescas campsite disaster in the Central Spanish Pyrenees, and its temporal and spatial context. Hydrological Processes 11: 1797-1812.

Zolina O, Simmer C, Kapala A, Bachner S, Gulev S, Maechel H. 2008. Seasonally dependent changes of precipitation extremes over Germany since 1950 from a very dense observational network. J. Geophys. Res. 32: D113. 


\section{FIGURE LEGENDS}

Figure 1. Location of the study area and observatories.

Figure 2. Spatial distribution of average annual values of indices of daily precipitation in the study area over the period 1955-2006.

Figure 3. Annual evolution (original and smoothed series) and temporal trends for total precipitation $\mathrm{P}$ at three selected observatories.

Figure 4. Signs of trends and percentage change per decade for the nine annual precipitation indices in the study area for the period 1955-2006.

Figure 5. Scatter plot of P trends trends vs PI, R5GD and WD trends.

Figure 6. Scatter plot of C90 vs PI and R5GD trends.

Appendix 1 to 4. As for Fig. 4, but for the winter (from December to February), Spring (from March to May), Summer (from June to August) and Autumn (from September to November) seasons. 


\begin{tabular}{clc}
\hline Acronym & Definitions & Unit \\
\hline P & Total precipitation & $\mathrm{mm}$ \\
WD & Number of wet days (precipitation $>1 \mathrm{~mm})$ & days \\
PI & Simple daily intensity (P/WD) & $\mathrm{mm}$ \\
C90 & Annual 90th percentile & $\mathrm{mm}$ \\
R90N & N of events with precipitation greater than long-term 90th & days \\
R90T & percentile (P90) & $\%$ \\
R5GD & Greatest 5-day total precipitation & mm \\
WS & Max No of consecutive wet days (precipitation $>1 \mathrm{~mm}$ ) & days \\
DS & Max No of consecutive dry days (precipitation $<1 \mathrm{~mm}$ ) & days \\
\hline
\end{tabular}

Table 1. Acronyms and definition of the nine selected precipitation indices. 


\begin{tabular}{|c|c|c|c|c|c|c|c|c|c|}
\hline & & \multicolumn{4}{|c|}{ WD } & \multicolumn{4}{|c|}{ R90N } \\
\hline & & - & $\mathbf{O}$ & + & Total & - & O & + & Total \\
\hline \multirow{4}{*}{ A } & - & 81 & 56 & 9 & 146 & 98 & 47 & 1 & 146 \\
\hline & O & 36 & 27 & 6 & 69 & 9 & 53 & 7 & 69 \\
\hline & + & 0 & 1 & 1 & 2 & 0 & 0 & 2 & 2 \\
\hline & Total & 117 & 84 & 16 & 217 & 107 & 100 & 10 & 217 \\
\hline
\end{tabular}

Table 2. Contingency between the trend signs of $P$ with those of WD and R90N. 


\begin{tabular}{|c|c|c|c|c|c|c|c|c|c|c|c|c|c|c|c|}
\hline \multirow[t]{2}{*}{ Indices } & \multicolumn{3}{|c|}{ Annual } & \multicolumn{3}{|c|}{ DJF } & \multicolumn{3}{|c|}{ МАM } & \multicolumn{3}{|c|}{ JJA } & \multicolumn{3}{|c|}{ SON } \\
\hline & - & $\mathbf{0}$ & + &  & $\mathbf{0}$ & + & - & $\mathbf{0}$ & + & - & $\mathbf{0}$ & + & - & $\mathbf{0}$ & + \\
\hline $\mathbf{P}$ & 68 & 32 & 0 & 58 & 4 & 0 & 42 & 57 & 0 & 46 & 53 & 0 & 20 & & 7 \\
\hline & & 39 & 7 & 9 & 38 & 3 & & 52 & 7 & 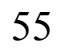 & 43 & 2 & & 72 & 26 \\
\hline $\mathbf{P}$ & 4 & 42 & 14 & 35 & 49 & 16 & 4 & 55 & 11 & 0 & 55 & 15 & 2 & 44 & 3 \\
\hline & & 4 & 11 & & 61 & 13 & & 60 & 12 & & 56 & 16 & & 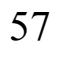 & 35 \\
\hline & 49 & 46 & 5 & 34 & 60 & 6 & 27 & 69 & 4 & 2 & 63 & 5 & 32 & 61 & 7 \\
\hline & & 62 & 0 & 17 & 74 & 9 & 12 & 76 & 12 & 21 & 65 & 14 & 31 & 62 & 7 \\
\hline & 44 & 50 & 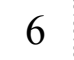 & 37 & 60 & 3 & 32 & 66 & 2 & 38 & 59 & 3 & 24 & 69 & 7 \\
\hline & 30 & 61 & J & 34 & 62 & 4 & 25 & 63 & 12 & 50 & 47 & 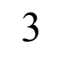 & 8 & 72 & 19 \\
\hline DS & 5 & 57 & 38 & 4 & 73 & 23 & 0.1 & 85 & 14 & 9 & 60 & 31 & 20 & 71 & 9 \\
\hline
\end{tabular}

Table 3. Percentage of observatories with positive $(+, \alpha<0.05)$, unchanged $(0, \alpha<0.05)$ and negative $(-, \alpha<0.05)$ trends in precipitation indices. 


\begin{tabular}{|c|c|c|c|c|c|c|c|c|c|c|c|c|c|c|c|c|}
\hline & \multicolumn{8}{|c|}{ Significance of Chi-squared test } & \multicolumn{8}{|c|}{ Coefficient of Contingency } \\
\hline & $\overline{\text { WD }}$ & PI & C90 & R90N & R90T & R5GD & $\mathbf{W S}$ & DS & WD & PI & C90 & R90N & R90T & R5GD & $\mathbf{W S}$ & 5 \\
\hline $\mathbf{P}$ & o & $* *$ & $* *$ & $* *$ & $* *$ & $* *$ & o & $*$ & 0.17 & 0.44 & 0.43 & 0.56 & 0.42 & 0.51 & 0.13 & 0.1 \\
\hline WD & & $* *$ & $* *$ & o & $*$ & o & $* *$ & $* *$ & & 0.44 & 0.33 & 0.14 & 0.23 & 0.08 & 0.35 & 0.4 \\
\hline PI & & & $* *$ & $* *$ & $* *$ & $* *$ & $*$ & $\mathrm{o}$ & & & 0.67 & 0.56 & 0.59 & 0.50 & 0.19 & 0.1 \\
\hline C90 & & & & $* *$ & $* *$ & $* *$ & o & o & & & & 0.65 & 0.64 & 0.41 & 0.18 & 0.1 \\
\hline R90N & & & & & $* *$ & $* *$ & o & o & & & & & 0.65 & 0.45 & 0.12 & 0.1 \\
\hline R90T & & & & & & $* *$ & o & o & & & & & & 0.55 & 0.11 & 0.1 \\
\hline R5GD & & & & & & & o & o & & & & & & & 0.11 & 0.0 \\
\hline WS & & & & & & & & o & & & & & & & & 0.1 \\
\hline
\end{tabular}

Table 4. Significance of Chi-squared test and coefficients of contingency from the crosstabulation analysis for the nine daily precipitation indices. 


\begin{tabular}{|c|c|c|c|c|c|c|c|c|c|c|c|c|c|c|c|c|}
\hline & \multicolumn{8}{|c|}{ WINTER (DEF) } & \multicolumn{8}{|c|}{ SPRING (MMA) } \\
\hline & WD & PI & C90 & R90N & R90T & R5GD & WS & DS & WD & PI & C90 & R90N & R90T & R5GD & WS & DS \\
\hline $\mathbf{P}$ & 0.22 & 0.43 & 0.46 & 0.51 & 0.31 & 0.62 & 0.44 & 0.09 & 0.5 & 0.52 & 0.59 & 0.49 & $\mathbf{0 . 3 9}$ & 0.68 & 0.18 & 0.13 \\
\hline WD & & 0.21 & 0.14 & 0.27 & 0.12 & 0.3 & 0.49 & 0.47 & & 0.3 & 0.14 & 0.19 & 0.21 & 0.12 & 0.47 & 0.23 \\
\hline PI & & & 0.68 & 0.45 & 0.45 & 0.49 & 0.1 & 0.16 & & & 0.67 & 0.5 & 0.36 & 0.54 & 0.13 & 0.2 \\
\hline C90 & & & & 0.57 & 0.57 & 0.47 & 0.08 & 0.19 & & & & 0.56 & 0.43 & 0.6 & 0.15 & 0.16 \\
\hline R90N & & & & & 0.57 & 0.49 & 0.22 & 0.1 & & & & & 0.56 & 0.59 & 0.06 & 0.07 \\
\hline R90T & & & & & & 0.43 & 0.21 & 0.21 & & & & & & 0.47 & 0.13 & 0.05 \\
\hline R5GD & & & & & & & 0.22 & 0.11 & & & & & & & 0.12 & 0.13 \\
\hline \multirow[t]{3}{*}{ WS } & & & & & & & & 0.13 & & & & & & & & 0.13 \\
\hline & \multicolumn{8}{|c|}{ SUMMER (JJA) } & \multicolumn{8}{|c|}{ AUTUMN (SON) } \\
\hline & $\overline{\text { WD }}$ & PI & C90 & R90N & R90T & R5GD & WS & DS & WD & PI & C90 & R90N & R90T & R5GD & WS & DS \\
\hline $\mathbf{P}$ & 0.18 & 0.39 & 0.32 & 0.43 & 0.22 & 0.6 & 0.15 & 0.2 & 0.19 & 0.45 & 0.44 & 0.59 & 0.43 & 0.67 & 0.16 & 0.17 \\
\hline WD & & 0.20 & 0.16 & 0.08 & 0.16 & 0.21 & 0.35 & 0.48 & & 0.22 & 0.1 & 0.13 & 0.12 & 0.15 & 0.21 & 0.14 \\
\hline PI & & & 0.66 & 0.49 & 0.52 & 0.57 & 0.22 & 0.2 & & & 0.66 & 0.47 & 0.55 & 0.53 & 0.11 & 0.2 \\
\hline C90 & & & & 0.52 & 0.59 & 0.49 & 0.29 & 0.19 & & & & 0.55 & 0.52 & 0.61 & 0.07 & 0.18 \\
\hline R90N & & & & & 0.6 & 0.54 & 0.23 & 0.1 & & & & & 0.64 & 0.63 & 0.09 & 0.17 \\
\hline R90T & & & & & & 0.45 & 0.3 & 0.09 & & & & & & 0.6 & 0.14 & 0.13 \\
\hline R5GD & & & & & & & 0.12 & 0.15 & & & & & & & 0.07 & 0.12 \\
\hline WS & & & & & & & & 0.27 & & & & & & & & 0.15 \\
\hline
\end{tabular}

Appendix 5. Coefficients of contingency from the cross-tabulation analysis for the nine daily indices on a seasonal basis. Bold numbers indicate those spatial associations significant at the $95 \%$ level, according to the Chi-squared test. 


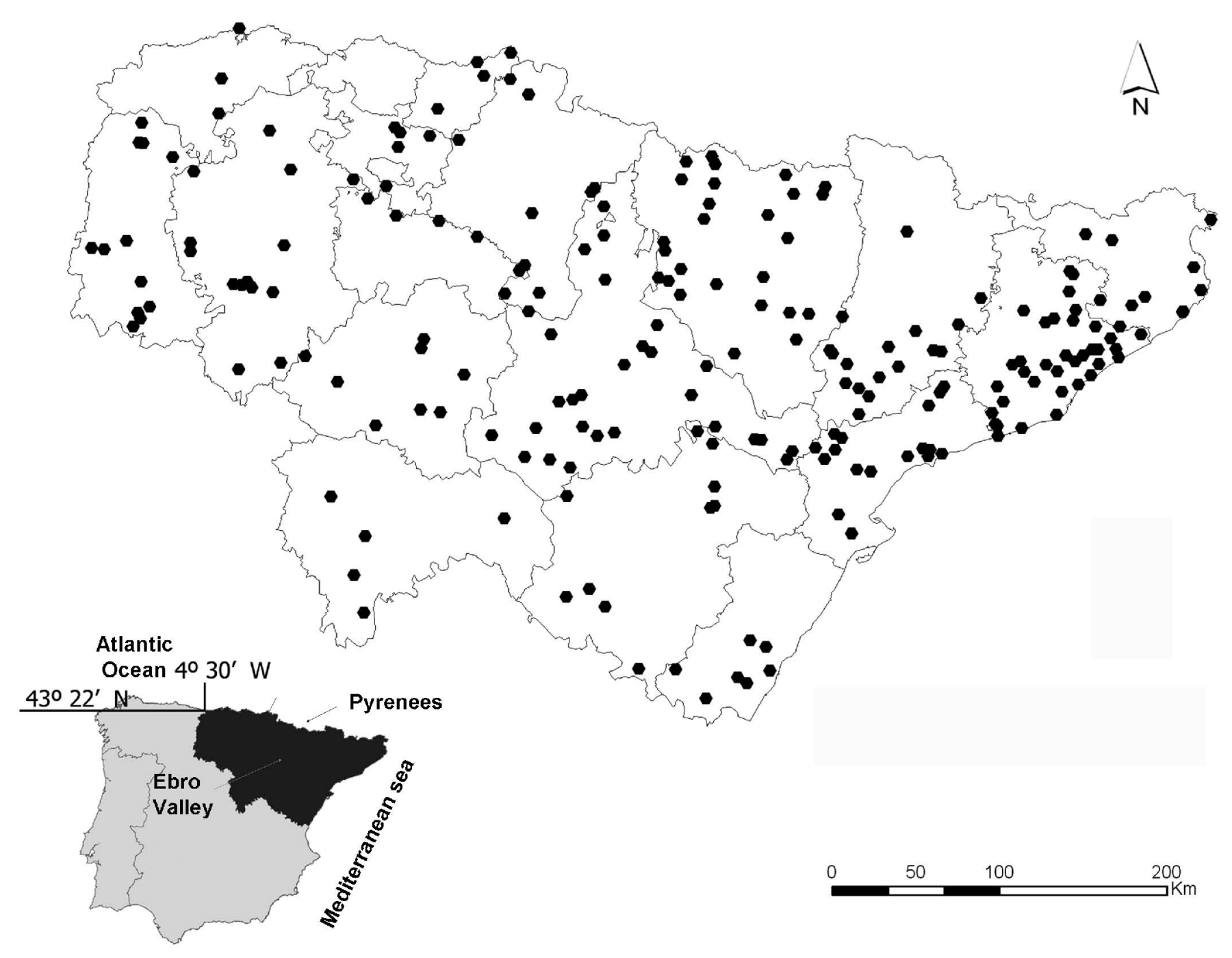



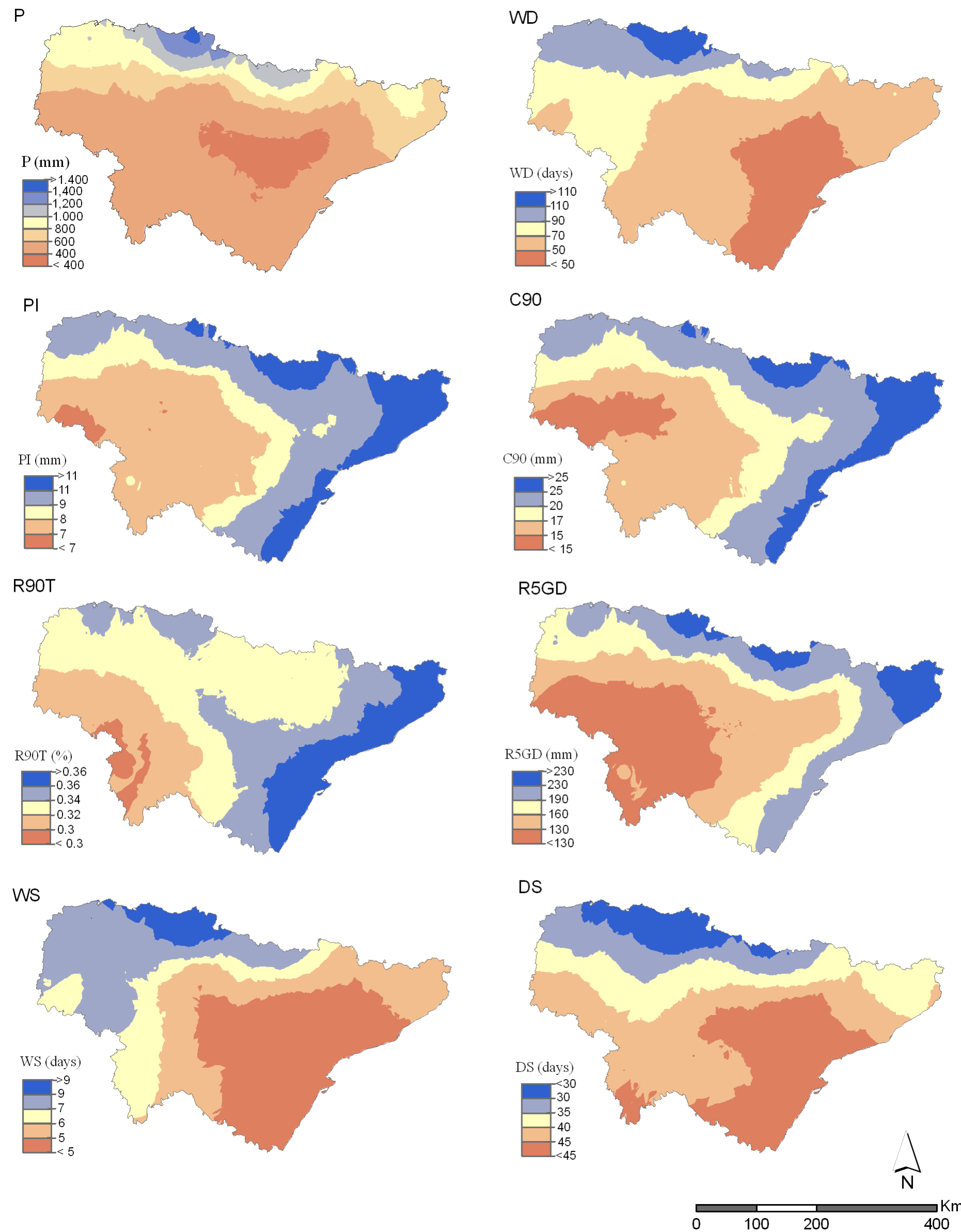



$$
\text { DS }
$$



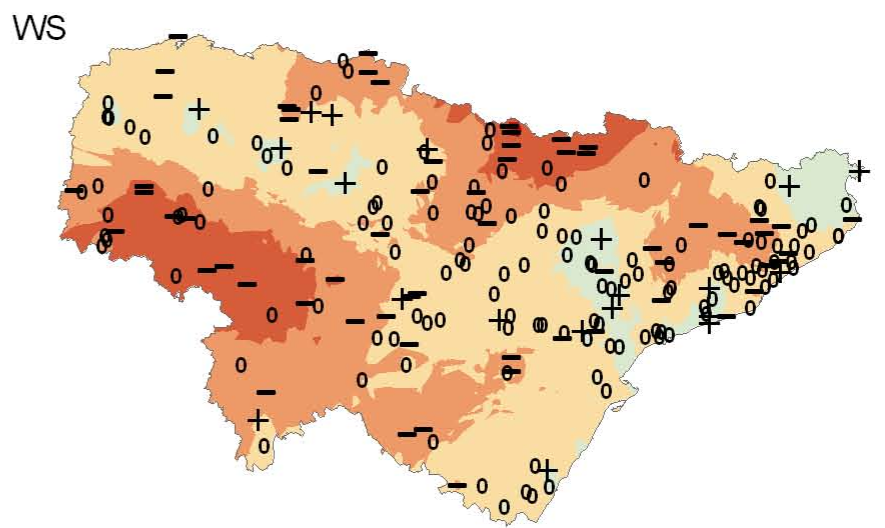


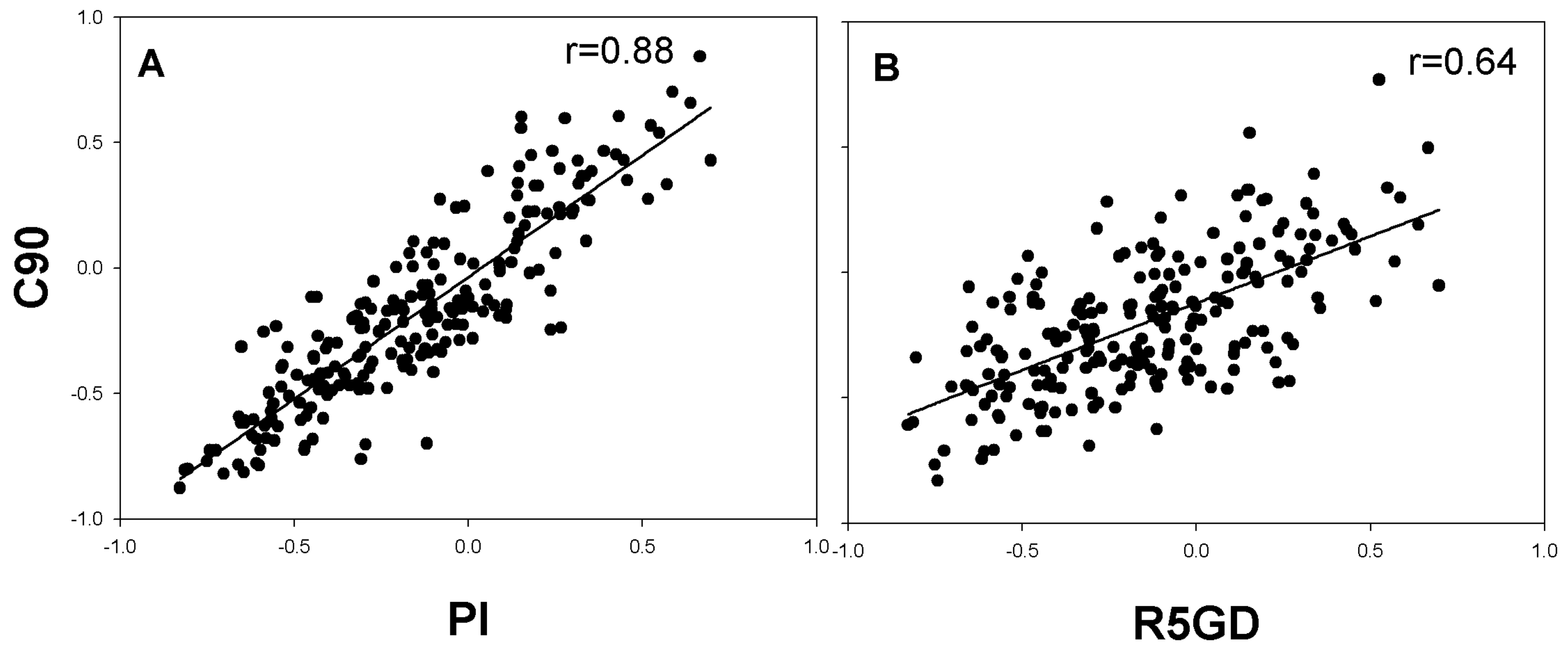

R5GD 

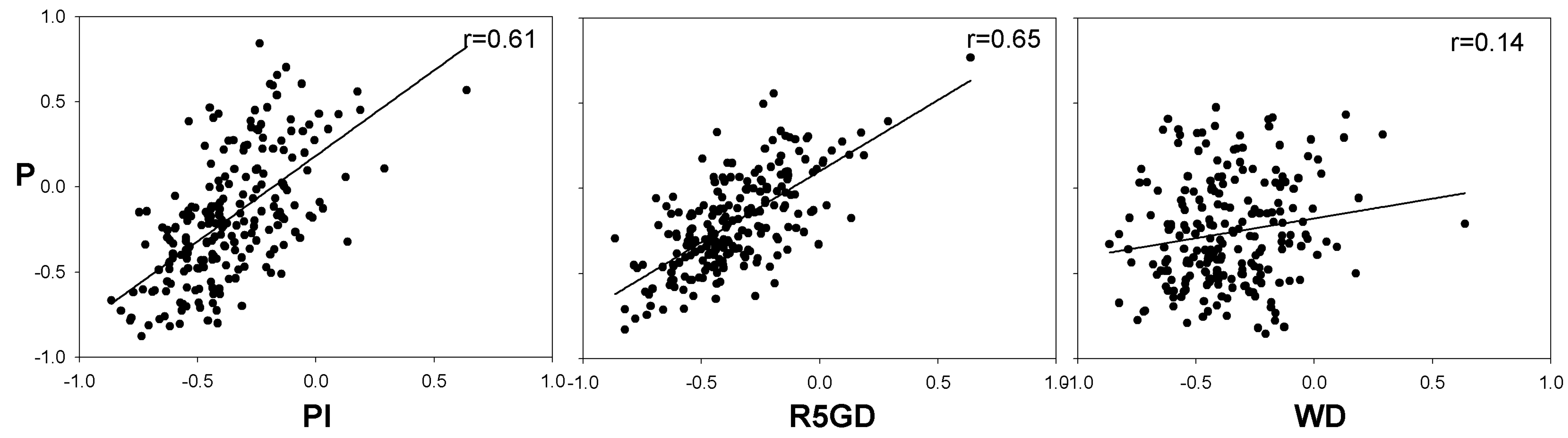

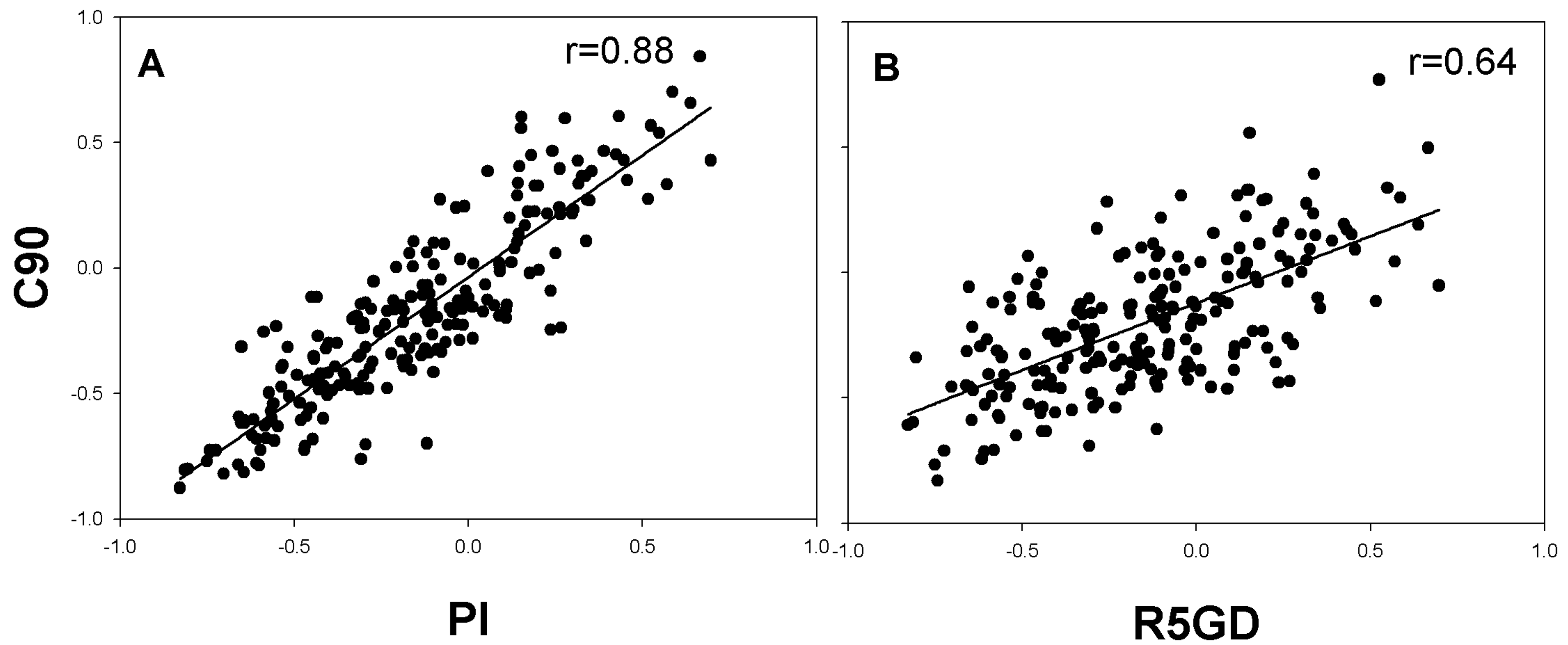

R5GD 

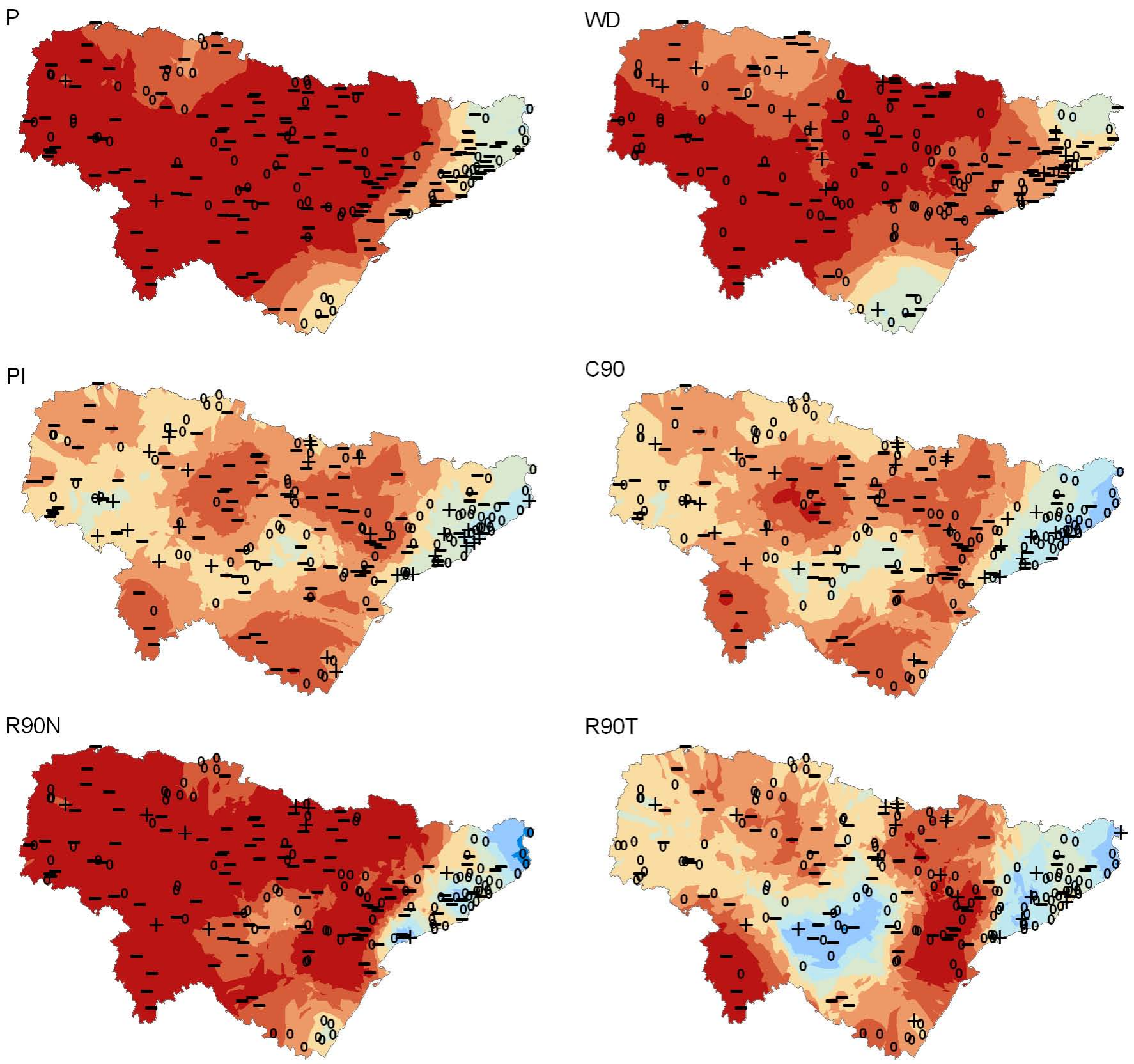

R5GD
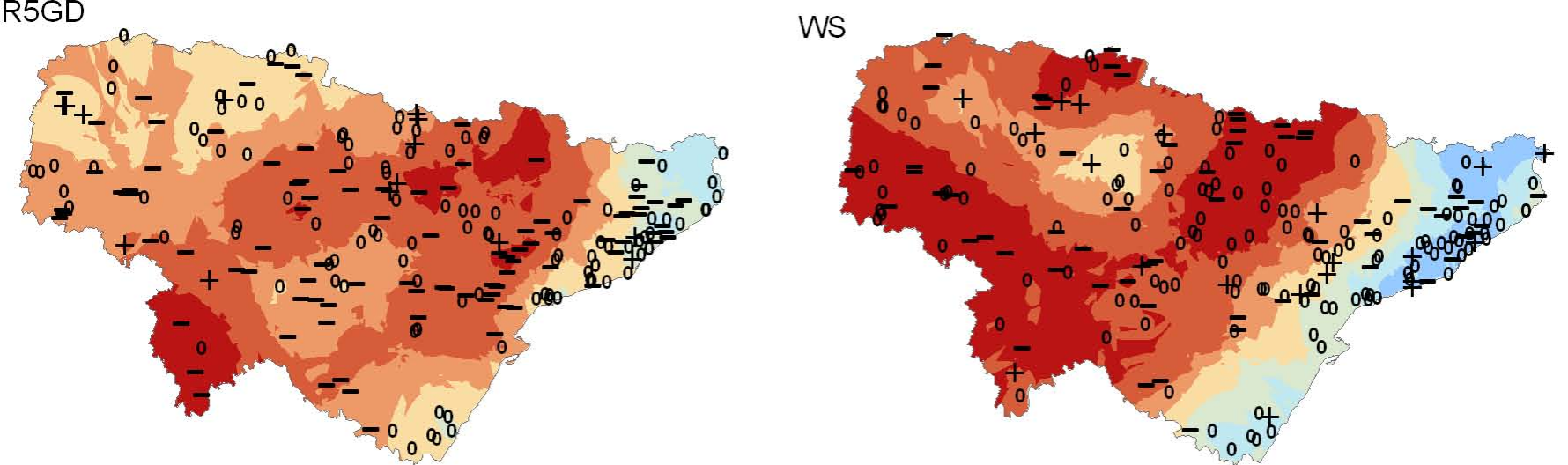

DS

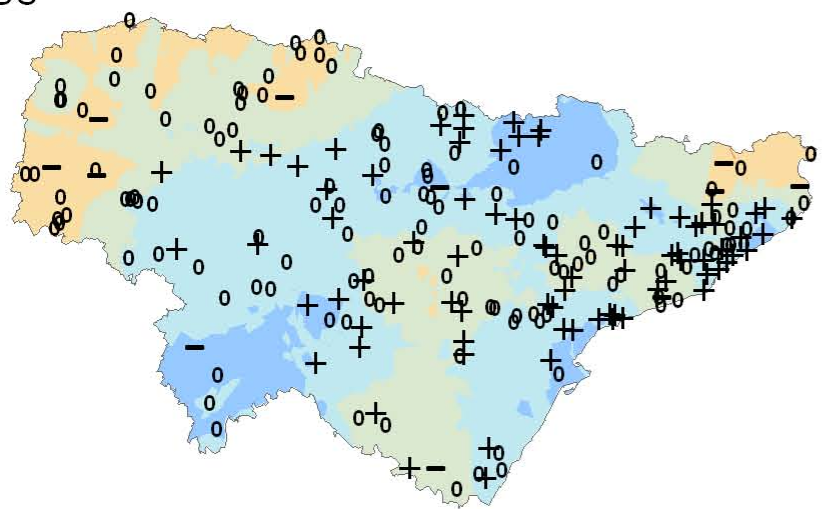
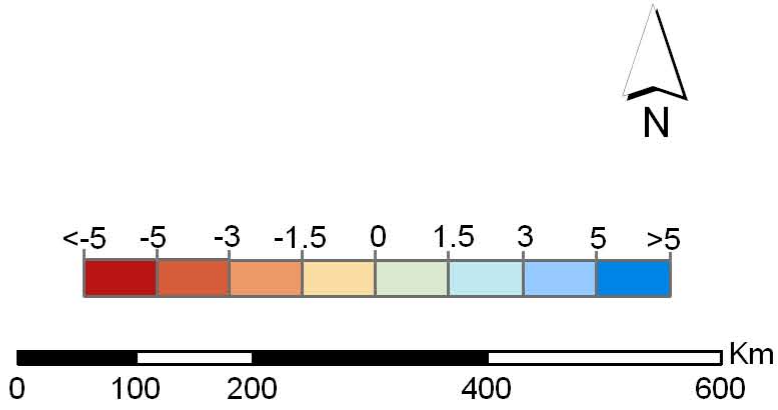
P

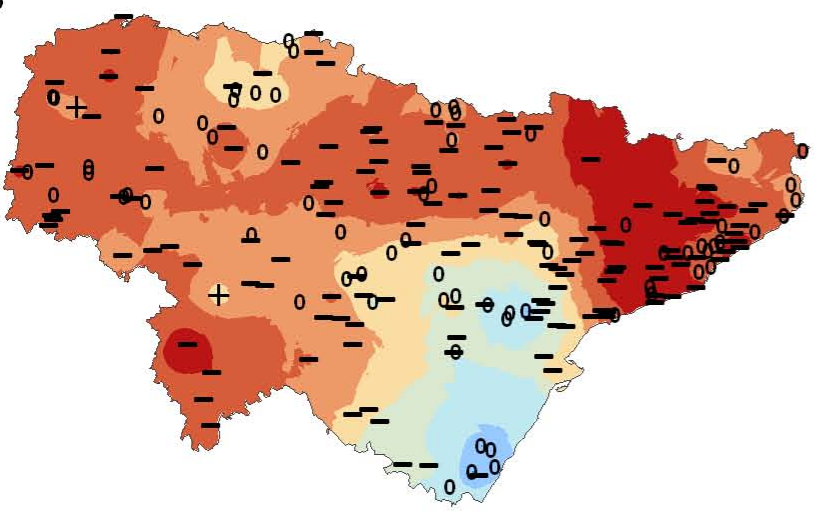

$\mathrm{Pl}$

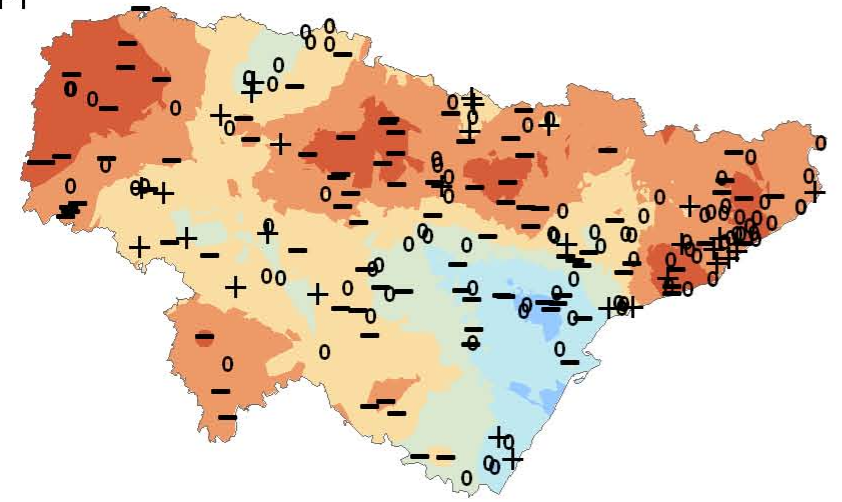

R90N

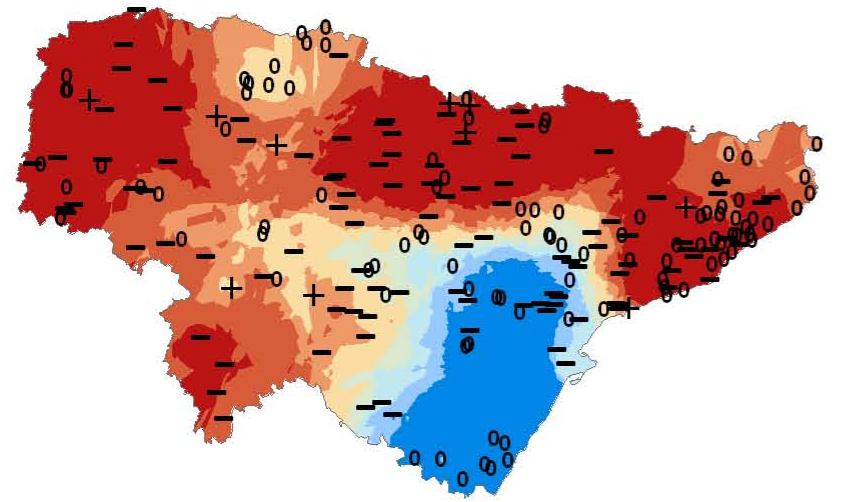

R5GD

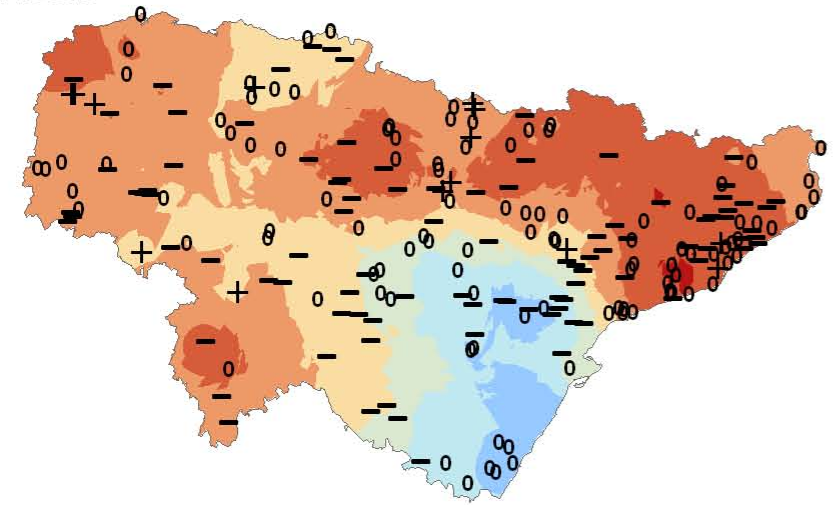

DS

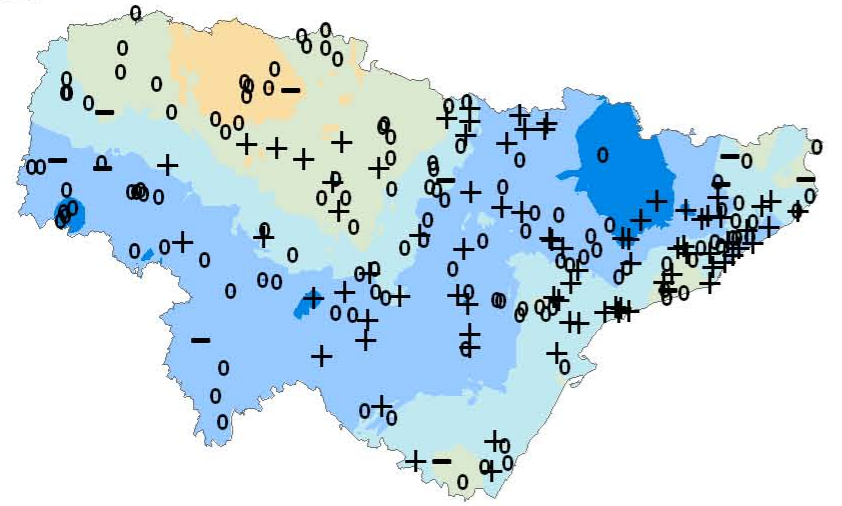

WD

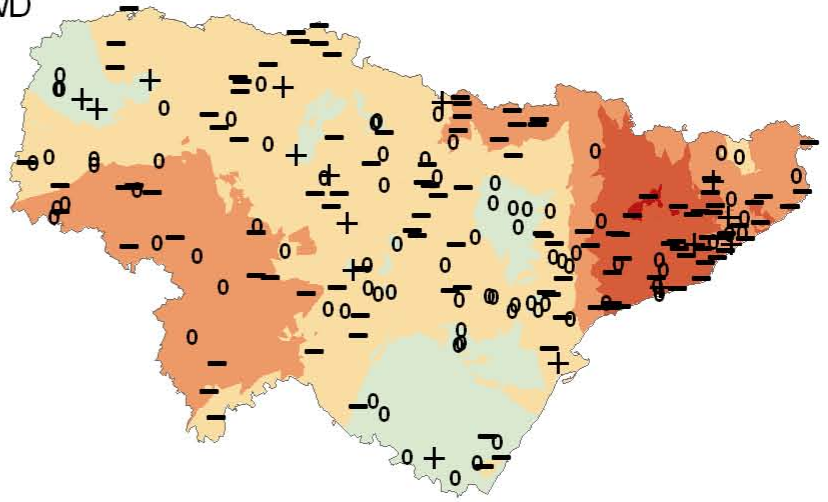

C90

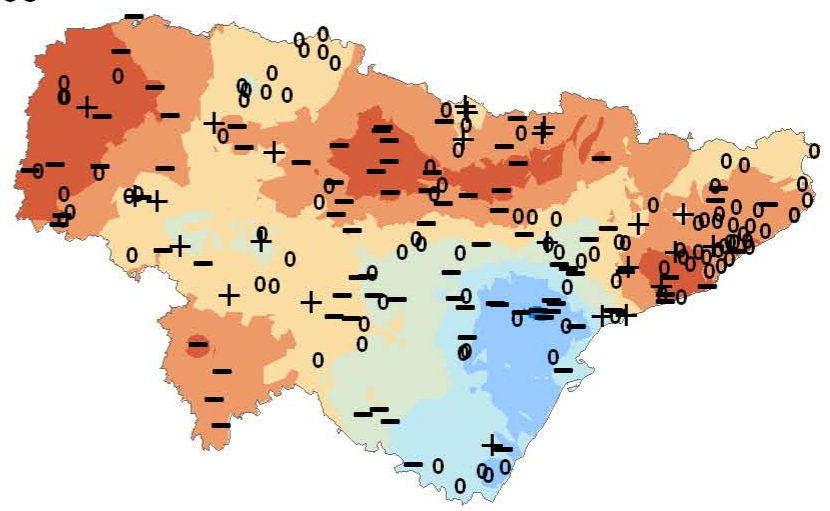

R90T

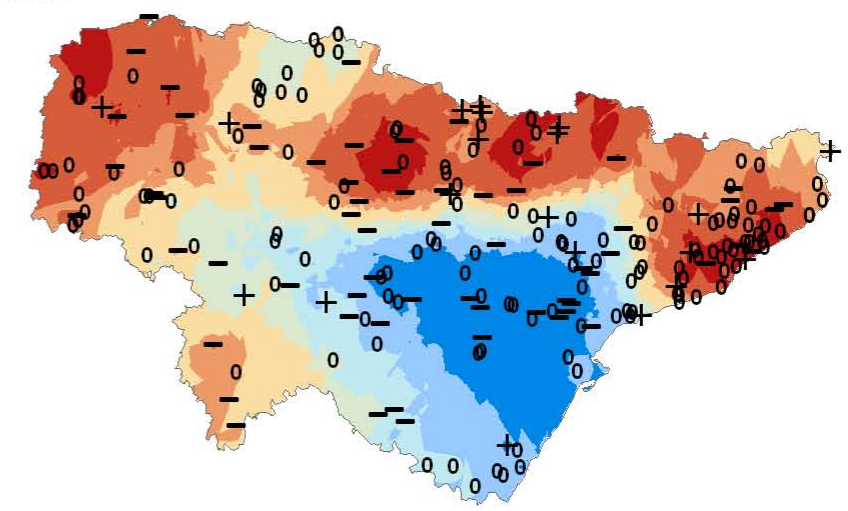

WS

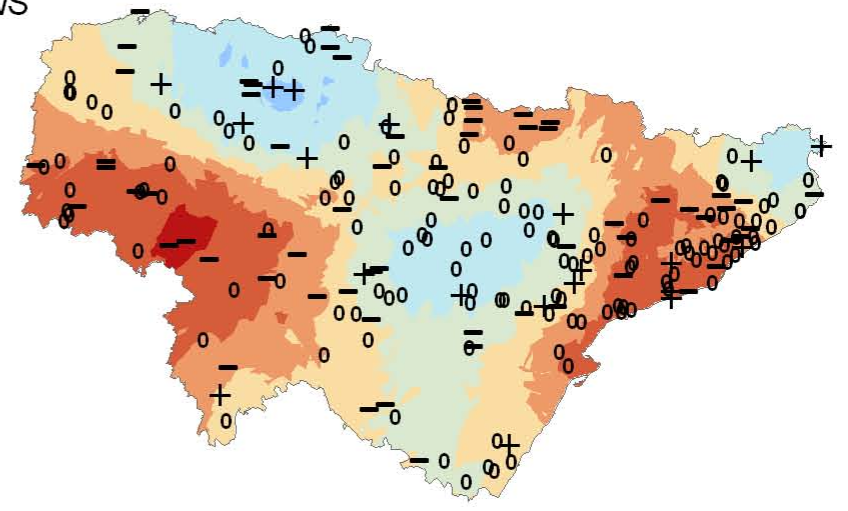


P

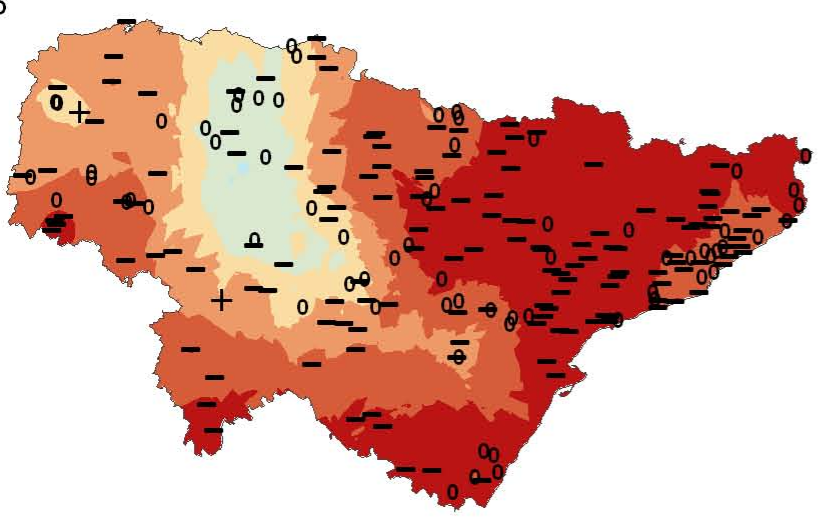

PI



R90N



R5GD

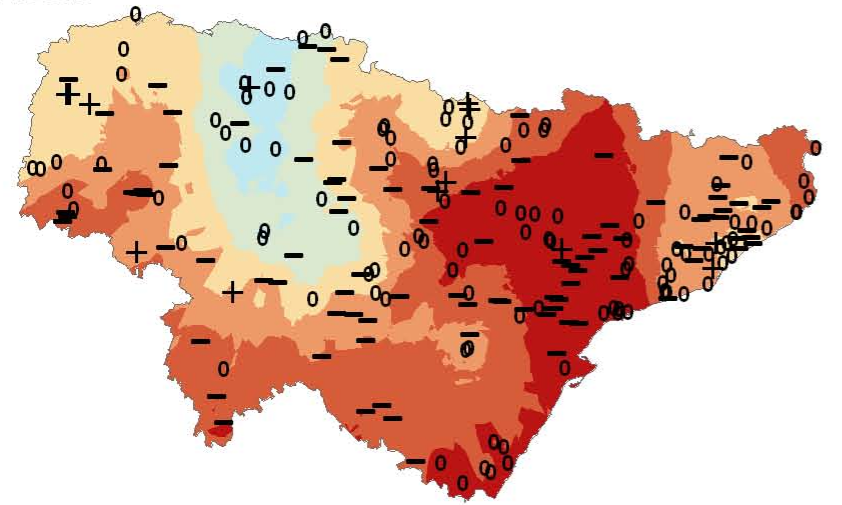

DS

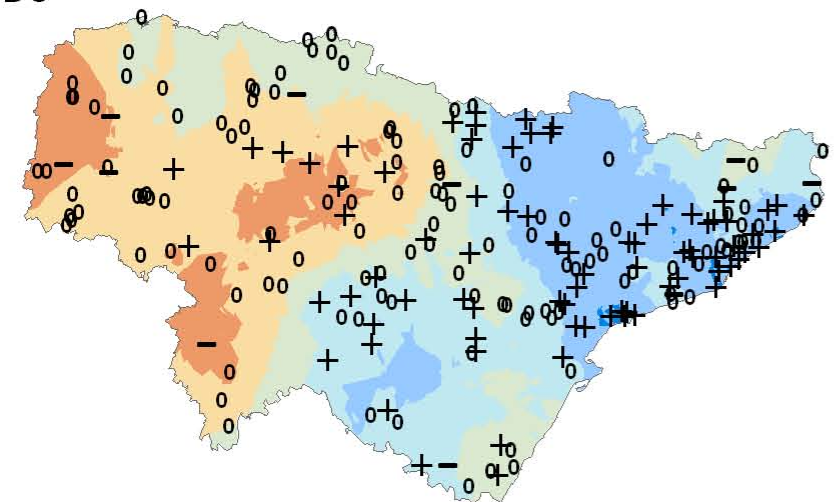

WD

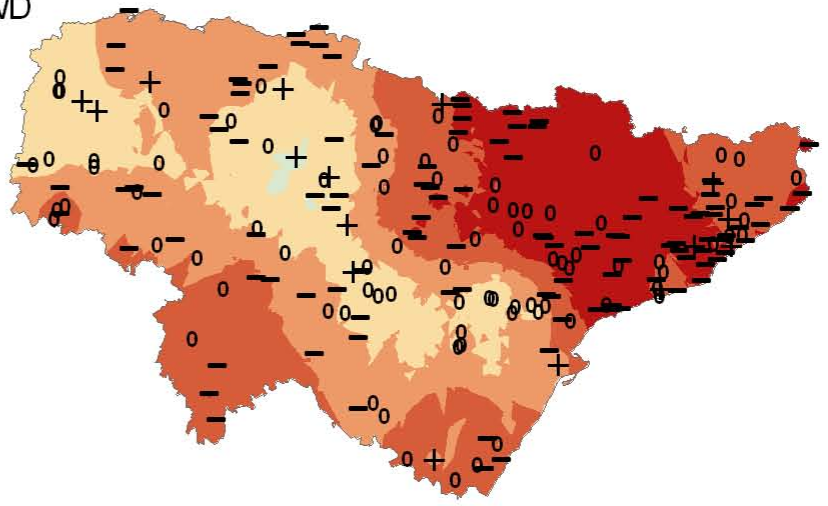

C90

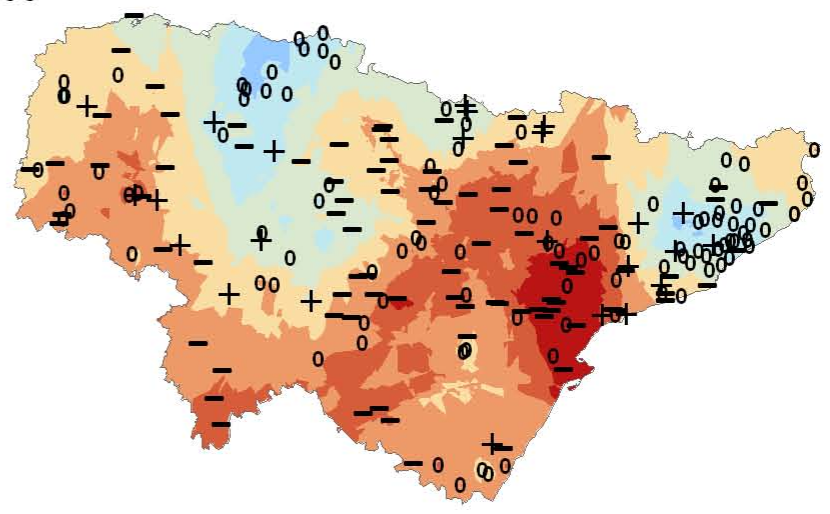

R90T



WS



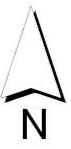

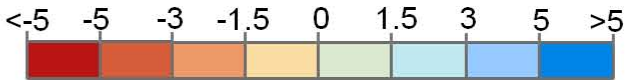



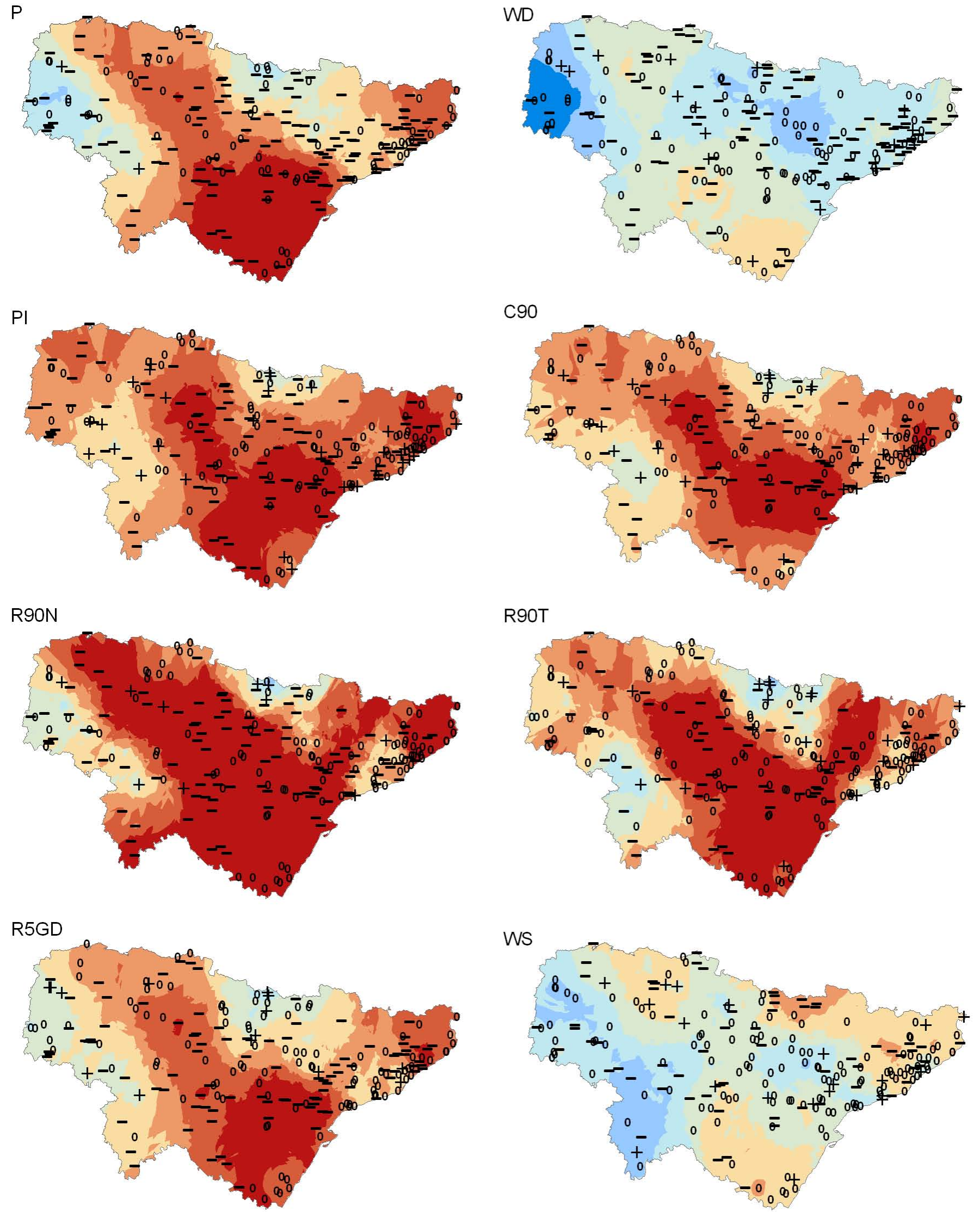

DS
